Capel, S. and Blair, R. (2007) Making physical education relevant: Increasing the impact of initial teacher education, London Review of Education, 5 (1), 15-34

\title{
Making physical education relevant: Increasing the impact of initial teacher training
}

\section{Susan Capel and Richard Blair, Brunel University}

\begin{abstract}
This paper is developed from concern that, despite a number of developments and initiatives in physical education over recent years, there has been little change in the teaching of the subject. This has resulted in many young people being alienated from physical education and therefore physical activity. The paper focuses on how initial teacher training (ITT) contributes to this lack of change by focusing on the development of knowledge for teaching and the technical competence to deliver this. It then considers ways in which ITT could contribute to developing 'knowledgeable teachers' who are able to make change. The paper focuses on two aspects identified as relevant for trainee physical education teachers: socialisation and knowledge for teaching. It recognises that the issues are complex and that change is difficult. It also recognises that ITT cannot change things by itself. However, it argues that by maintaining the status quo, the subject will not develop so that it is relevant to today's youngsters.
\end{abstract}




\section{Making physical education relevant: Increasing the impact of initial teacher training}

\section{INTRODUCTION}

Over recent years there have been a number of developments and initiatives in physical education. These include, for example, teaching games for understanding, sport education, cooperative learning and, in England, the introduction and development of the National Curriculum for Physical Education (NCPE). Despite this, it is generally recognised that there has been little change in the teaching of the subject (see, for example, Curtner-Smith, 1999; Evans et. al., 1997; Laws and Aldridge, 1995; Penney and Harris, 1998). Thus, the traditional, multi-activity curriculum based on the acquisition and performance of skills organised mostly around team games still predominates and a limited range of teaching methods are used for delivering this content (see, for example, Curtner-Smith, 1999; Fairclough and Stratton, 1997; Green, 1998; Kirk and Kinchin, 2003; Mawer, 1999; Metzler, 2000; OfSTED, 1995b, 2002; Penney and Evans, 1994; 1999). This traditional content and teaching approaches contribute to the alienation of many young people from physical education and therefore physical activity (see Kirk and Macdonald, 1998). This is partly because the physical education taught in schools does not allow young people to participate in the types of sport, exercise and physical recreation experienced outside school. Indeed, Kirk and Macdonald (1998: 381) argue that 'the form of learning represented in school may have little transfer value to related situations outside school. This is problematic if the aim of school physical education is to prepare pupils to pursue an active lifestyle in adulthood'. Low participation in a physically active, healthy lifestyle after leaving school is worrying, particularly at a time when the incidence of obesity is rising.

The aim of this paper is to consider factors in initial teacher training (ITT) which contribute to this lack of change in the teaching of physical education, focusing on socialisation into teaching and the conceptualisation of knowledge for teaching employed on any one ITT programme, as well as the way in which programmes are structured and delivered. The paper then aims to identify some ways in which ITT could contribute to developing 'knowledgeable teachers' of physical education who are able to make change. It is recognised that the issues are complex and that change is difficult. It also recognises that ITT cannot change things by itself. 
Two theoretical perspectives are considered: teacher socialisation and knowledge for teaching.

\section{Socialisation}

The strength of socialisation into teaching physical education has been recognised over a long period. Research, much based on that initially conducted by Lortie (1975) and then Lawson (1983a; 1983b), has identified a number of socialising factors which shape physical education teachers knowledge and beliefs about the purpose of physical education, its content and teaching approaches. These include experiences in physical education (Curtner-Smith, 1999; Evans and Williams, 1989; Green, 1998; Schempp, 1989), sport (both in an out of school) (Curtner-Smith, 1999; Dewar and Lawson, 1984; Dodds et. al., 1992; Templin, 1979), success in education and in sport (Evans et. al. 1995) and interactions with physical education teachers, coaches and others working in physical activity and sport contexts with whom the prospective teacher comes into contact (Mawer, 1996). Some of these experiences are likely to be stronger than others for a number of reasons. For example, research has shown that many physical education teachers are motivated to enter the profession because of their experiences, and success, in sport as opposed to physical education (see, for example, Stidder and Hayes, 2006).

The history of the subject generally, and of the training of physical education teachers specifically, contribute to the strong socialising influences. Physical education has traditionally been gendered (see, for example, Brown, 2005; Flintoff, 1983; Williams and Bedward, 2001). Different rationale for and content of physical education for boys and girls in schools has resulted from perceived differences in need and appropriateness for boys and girls. For example, physical education was included in boys public schools to prepare them for their role in the military; focusing both on character building and health and fitness, whilst for girls it was included for the remedial and educational possibilities of exercise. Thus, physical education was traditionally taught in single sex classes (OfSTED, 1995a). As a result, the early training of physical education teachers was in single sex institutions (see, for example, Kirk, 1992), with different programmes designed to enable men and women to teach different curricula in schools (see Fletcher, 1984). Despite the training of teachers no 
longer being single sex, much teaching of physical education in schools remains single sex. Thus, gender has a significant impact on the socialisation of trainee physical education teachers (see for example, Brown, 2005; Flintoff and Scraton, 2001; Rich, 2001; Stidder and Hayes, 2006).

In a study of knowledge about and confidence to teach the six areas of activity in the NCPE, Capel and Katene (2000) identified gender differences in trainee physical education teachers perceptions in relation to some activities. The activities which the highest percentage of male trainees identified as those in which they perceived little knowledge were netball, dance, swimming and outdoor and adventurous activities (OAA); whilst the activities identified by the highest percentage of female trainees were cricket, dance, OAA, rugby and football. Male trainees perceived significantly greater knowledge than female trainees of football, whilst female trainees perceived significantly greater knowledge than male trainees of netball, rounders, OAA and swimming. Further, a higher percentage of male trainees identified traditional male games of football and rugby as well as badminton and athletics and a higher percentage of female trainees identified traditional female games of netball and rounders as well as swimming and gymnastics as activities in which they perceived good knowledge. On the other hand, male trainees identified netball and swimming and female trainees identified rugby, football and athletics as activities in which they perceived little knowledge.

Differences in perceptions of amount of knowledge by male and female trainees were related to the different backgrounds and experiences which these trainees brought to their ITT programme because they were taught different activities in the school physical education curriculum and had different opportunities for participation in extra-curricular activities and outside school. Male trainees are more likely to have been taught football, rugby and cricket and female trainees are more likely to have been taught hockey, netball and rounders whilst at school. Also, male trainees may have experienced a more limited curriculum than female trainees. OFSTED (1995a: 12) found that 'in a substantial proportion of schools...the programme for boys is sometimes more limited than for girls'. Thus, the historical legacy of physical education, particularly the single sex teaching of the subject and the training of teachers, have perpetuated the development of gender specific curricula. This, in turn, affects the actions and attitudes of male and female physical education teachers. 
As a result of their experiences, the beliefs held by many physical education teachers are 'conservative', based on a 'sporting perspective' in which the focus is on improving performance in traditional [British] team games (Sparkes, 1991b), delivered mainly through didactic approaches.

These beliefs have 'a distinct and traceable influence on an individual's future decisions, practices, and ideologies as a teacher' (Schempp and Graber, 1992: 333). Many physical education teachers see content and teaching approaches as 'self-evident' and 'unproblematic' (Thomson, 1999), resulting in what Penney and Evans (2005: 21) called 'the taken-forgranted routines in physical education'. As a result, any change in response to a development or an initiative may be superficial (e.g. use of new curriculum materials) (Sparkes, 1991a). Practice is not changed and the intended outcome is not achieved; the teacher continues to work within their comfort zone using established routines and practices that they do not want disrupted. For example, Evans and Penny (1992) and Penney and Evans (1997) have found that many teachers in England adapt, modify and recreate the NCPE to match their existing beliefs. Likewise, despite the use of less directed teaching approaches in sport education, Alexander and Luckman (2001) warned that the focus on pupil-led organisation may encourage teachers to settle for, what Placek (1983) called, 'the busy, happy and good' approach to teaching, rather than seriously attempting to promote learning.

Thus, the call for fundamental curriculum change continues to be a key theme in physical education (e.g., Corbin, 2002; Locke, 1992; Penney and Chandler, 2000). To make such change will require what Sparkes (1991a: 2) called real change, in which 'a key dimension for consideration is the transformation of beliefs, values and ideologies held by teachers that inform their pedagogical assumptions and practices'. Real change is very difficult. Indeed, Sparkes (1987) questioned whether the constraints of entrenched cultural norms of physical education enable any change to be made. If any change is to be made, ITT, the first formal, structured development of knowledge, understanding and skills for teaching physical education must be a key component.

\section{Knowledge for teaching}


The second theoretical perspective considered is knowledge for teaching; particularly that knowledge developed in ITT. The knowledge and beliefs trainee teachers bring with them to ITT about physical education and about teaching, the knowledge they (chose to) learn during their programme and therefore the knowledge they have at the end of their programme and how they then use that knowledge in school is a result of both socialisation prior to and during their programme and the way in which knowledge for teaching is conceptualised within any one ITT programme.

Although one characteristic of a profession is its conceptual body of knowledge (see Hoyle and John, 1995), the knowledge that distinguishes teachers as professionals is contested. Thus, there are a number of theoretical models, ranging from rationalistic to interpretive, which conceptualise this knowledge.

\section{Different ways of conceptualising knowledge for teaching}

In a review of changes in the knowledge base deemed appropriate to underpin teacher education in England, Hoyle and John (1995) highlighted underpinning knowledge based on the theories of Rousseau and Dewey being replaced by knowledge from the social science disciplines of history, philosophy, psychology and sociology of education. This generic approach to, and conclusions and recommendations about, teaching and learning, were translated into useable classroom activities in 'curriculum packages'. In turn, these underpinnings have been replaced by a number of other conceptualisations of knowledge for teaching. The action-research approach built on the ideas of Lewin (1946) and Stenhouse (1975). In this approach specific knowledge develops from 'systematic reflection on one's classroom experience, to understand it and to create meaning out of that understanding' (Hopkins, 2002: 5). This is related to the development of what Schon (1983) called the reflective practitioner. Schon suggested that the capacity to reflect on action so as to engage in a process of continuous learning is one of the defining characteristics of professional practice. Other conceptualisations of knowledge include that by Elbaz (1983), who categorised teachers' practical knowledge into: knowledge of self; knowledge of the milieu of teaching; knowledge of the subject matter; knowledge of the curriculum; and knowledge of instruction. For Leinhardt and Smith (1985), teacher knowledge comprised subject matter knowledge and knowledge of lesson structure. 
Hoyle and John (1995) grouped the different conceptualisations of knowledge for teaching into three rival epistemologies: positivist; interpretive; and critical. Bain (1990) identified socialisation as one of three paradigms for research into knowledge for teaching physical education: the other two being behaviourist and critical theory. Carter (1990) identified three overlapping approaches to learning to teach; information-processing: the cognitive processes teachers use in thinking about teaching; teachers' professional knowledge: which includes both personal, practical and classroom knowledge; and pedagogical content knowledge: knowledge about the subject matter and how that is translated into classroom practice. Munby et. al. (2001) classified the large number of ways in which knowledge for teaching can be conceptualised into theoretical or propositional and practice-orientated. They also recognised a 'gradual reconciliation [of the two] reinforces our view of the complexity involved in rendering the field into neat and exclusive categories' (p.878).

Thus, the concept of knowledge for teaching is problematic. Two conceptualisations of knowledge for teaching commonly used in physical education are considered in the next section: that of Shulman (1987), which has been the focus of much research in physical education; and competencies/standards, which underpin many ITT physical education programmes.

\section{Knowledge bases identified by Shulman}

The seven knowledge bases developed by Shulman $(1986 ; 1987)$ as the minimum knowledge for teaching is a framework commonly used in research about knowledge for teaching in general and in physical education in particular (e.g. Fernandez-Balboa et. al., 1996; Graber, 1995; Griffin et. al., 1996; Newton and Newton, 2001; Rovegno, 1992; Twiselton, 2000; see also a review by Amade-Escot, 2000). These knowledge bases are: Content knowledge (called subject matter knowledge by other researchers, e.g. Calderhead and Shorrock, 1997; Grossman et. al., 1989; McDiarmid et. al., 1989). It includes two structures of knowledge: what Schwab (1964) called substantive (knowing which are the important concepts and skills in the subject) and syntactic (knowing how the concepts and skills are structured and organised within the subject). General pedagogical knowledge, which includes the broad principles and strategies of classroom management and organisation that apply irrespective of 
the subject. Curriculum knowledge: the materials and programmes that serve as 'tools of the trade' for teachers. Pedagogical content knowledge: the knowledge that is the basis for the selection, organisation and presentation of the content teachers want their pupils to acquire; i.e. the integration of content and pedagogy for teaching physical education; that which makes the content instructional. Grossman (1990) identified four components of pedagogical content knowledge: knowledge and beliefs about the purposes of teaching a subject at different grade levels; knowledge of pupils' understanding, conceptions and misconceptions of subject matter; knowledge of curriculum materials available for teaching a subject and knowledge of horizontal and vertical curricula for the subject; knowledge of instructional strategies and representations for teaching particular topics. Knowledge of learners and their characteristics: both knowledge of learners of a particular age range (empirical or social knowledge) and cognitive knowledge of learners, comprising knowledge of child development and knowledge of a particular group of learners. Knowledge of educational contexts: including a specific school, catchment area and the wider community. Knowledge of educational ends, purposes, values and philosophical and historical influences: both short and long-term goals of physical education and of education. Within this framework, Shulman identifies pedagogical content knowledge as the key to defining and understanding teaching as a special area of expertise that separates the pedagogue from an instructor.

\section{A competency-based model of knowledge for teaching}

A commonly used conceptualisation of knowledge used in many ITT programmes is the identification, in a behaviourist, competency-based model, of the standards and skills which trainee teachers must achieve to qualify as a teacher. In England, there are three standards (Department for Education and Skills (DfES) and Teacher Training Agency (TTA), 2003) which are the minimum legal requirement of what trainee teachers must demonstrate they know, understand and are able to do to qualify as a teacher. These are: Professional values and practice (the attitudes and commitment to be expected of anyone qualifying to be a teacher); Knowledge and understanding (the content knowledge that gives newly qualified teachers (NQTs) confidence and authority in their subject; a clear understanding of how all pupils should progress and what teachers should expect them to achieve); Teaching (skills of planning, monitoring and assessment, and teaching and class management, underpinned by the values and knowledge covered in the other two standards). Within each of these three 
standards a number of individual standards are identified. These generic standards are applicable to trainee teachers learning to teach different age levels and different subjects; there are no separate standards for physical education.

\section{The limitations of these conceptualisations of knowledge}

Each conceptualisation of knowledge has its strengths and limitations. The next section looks at some limitations of Shulman's and competency-based conceptualisations of knowledge in informing ITT. It focuses first on the particular content of both conceptualisations and then on the way in which that content is organised and presented in a competency-based model (using the particular classification of standards in England as an exemplar).

Teaching is a complex activity and, out of the whole range of possible knowledge for teaching, each different conceptualisation of knowledge prioritises some knowledge over other knowledge. The specific knowledge prioritised by Shulman and in the standards in England is similar, although organised differently; Shulman's seven knowledge bases are incorporated into the three broad standards. Both prioritise knowledge for teaching and, in particular, the technical aspects of knowledge, e.g. the skills, rules and tactics of different sports activities, organisation and management, teaching approaches, managing behaviour.

However, even within the knowledge prioritised, some aspects of that knowledge seem to be given greater priority than other aspects. For example, the particular focus of much research in physical education based on Shulman's knowledge bases is on pedagogical content knowledge, which has provided considerable information about what teachers know, how they come to know it and therefore, how they go about teaching it (Segall, 2004: 491).

Those aspects of knowledge that enable trainee teachers to focus on the problematic nature of teaching physical education (e.g. why particular content is taught in a particular way and whether it achieves the aims of a particular physical education programme) are given less priority. These aspects look beyond the what and the how of the technical to the why, based on an individual's beliefs and values, formed as a result of particular experiences and social contexts. For example, what Shulman (1987) called 'Knowledge of educational ends, purposes, values and philosophical and historical influences' and one of the components of 
pedagogical content knowledge identified by Grossman (1990) 'knowledge and beliefs about the purposes of teaching a subject at different grade levels' seems to have been given lower priority, both by Shulman (1987), who described this knowledge as implicit rather than explicit, and in the research agenda.

As with Shulman's knowledge bases, more problematic aspects of knowledge for teaching and understanding beliefs and values are given lower priority in a competency-based model. They are only referred to explicitly in one standard in England and implicitly in another, i.e. ([trainee teachers] 'know and understand the values, aims and purposes and the general teaching requirements set out in the National Curriculum Handbook' (S2.2)), and 'demonstrate and promote the positive values, attitudes and behaviour that they expect from their pupils' (S1.3)).

The way in which the content is organised and assessed further reinforces the prioritisation of some knowledge over other. This is related to the structure of a particular ITT programme and in this case, of ITT in England. Much training of secondary teachers takes place through the one year (36 week) Postgraduate Certificate in Education (PGCE) route. On such programmes trainee teachers are required to spend 24 weeks in school and 12 in the university. Although both the school- and university-based parts of the programme are important and designed to complement each other, research (e.g. Capel et. al., 2006, Williams and Soares, 2002) suggests that trainee teachers learn more from the school- than from the university-based part of the programme. This is because assessment of their performance against the standards to qualify as a teacher largely occurs in school. Thus, the school-based mentor is particularly influential in what trainee teachers learn on the school-based part of the programme. If the school curriculum, and the mentor's and other teachers teaching approaches, are traditional, this will influence what and how a trainee physical education teacher teaches. This is exacerbated if the mentor is not open to other content or teaching approaches being used.

In a study of what trainee teachers learn in schools on a school-based ITT programme, Edwards and Protheroe (2003) found that learning is heavily situated, with trainee teachers learning about curriculum delivery without acquiring ways of interpreting learners that are easily transferable. They also found there to be a participatory version of training which is not 
underpinned by an understanding of the implications of learning. Wright and Bottery (1997) found that school-based mentors place considerable emphasis on practical classroom and personal development techniques, but do not focus on conceptions of the wider role of the teacher. Thus, there is a strong emphasis on only part of the process of training teachers. They indicated that these findings suggest a 'cloak of technical rationality shrouds the training of new entrants to teaching and that the profession is either unaware or unwilling to debate and initiate its new entrants into a rich professional culture' (p.235).

Specific, identifiable outcome statements or standards identified in competency-based models largely prioritise observable and measurable aspects of technical knowledge, therefore prioritise what trainee teachers can do rather than what they know. Knowledge which is not directly observable or is not amenable to precise measurement is given lower priority. This is further reinforced if, in order to qualify as a teacher, each trainee teacher is required to present evidence to 'tick off' achievement of each specific, observable outcome or standard. Such an approach can result in learning being atomised, whilst ignoring the holistic nature of teaching; that which makes teaching more than the sum of its parts. Thus, the interrelatedness, inter-dependence and complex interaction of knowledge that informs teaching decisions, regarded as important by Shulman (1987), can be lost. It can also result in trainee teachers developing knowledge which is limited to that which is applicable to the specific situation, rather than developing what Fernandez-Balboa et. al. (1996) called 'knowledge connectedness', which enables trainee teachers to transfer knowledge from one situation to another.

In prioritising technical knowledge for teaching which is transmitted to trainee teachers during ITT then assessed on the basis of achieving specific, mainly observable, outcomes, trainee teachers can learn the 'tricks of the trade' as they pick up what has variously been described as 'tips for teaching', a 'series of recipes' or a 'tool kit' for teaching. Indeed, Rossi and Cassidy (1999: 189) highlighted that "whilst this [technical] learning is important, it is sometimes elevated to a significance perhaps out of proportion with its functional utility and reduces the teacher to little more than a technician'. It results in teaching being regarded as a low-grade activity undertaken by trained technicians having served their apprenticeship. If this is the case can we really lay claim to teaching being a true profession? 
The outcomes of such an approach are that trainee teachers know how to teach, for example, the javelin (e.g. how to organise and manage the class and the most appropriate teaching approaches in light of the particular safety requirements), but not why they are teaching javelin rather than another activity, nor why they teach javelin, discus and shot each year rather than focusing on, for example, one of these as a representation of a category of activities. Likewise, they know what teaching approach to use to achieve a particular learning outcome, but may not be able to articulate why that outcome is important. Thus, the focus is on a process-product 'if do this, then that happens' model, rather than a model which focuses on why and the complex, problematic nature of teaching and learning and of physical education. Thus, there is a self-perpetuating cycle and prior socialisation tends to be reinforced. This limits the opportunities to challenge values and beliefs.

Whilst this section has not covered an exhaustive list of limitations, it points to the need to consider how trainee teachers can be prepared to do more than deliver competently the current curriculum using a limited range of teaching approaches. As presently conceptualised, ITT does not seem to be challenging the strong socialisation of physical education teachers. Research suggests that beliefs about physical education developed prior to ITT are not easily changed and that ITT has relatively little impact on trainee teachers (Curtner-Smith, 1999; Evans, 1992; Evans et. al., 1996; Green, 1998; Placek et. al., 1995). Further, research has found that in ITT many trainee teachers confirm, rather than modify, their values and beliefs (Doolittle et. al., 1993; Solmon and Ashy, 1995). The analysis above suggests that this is what is occurring on ITT programmes in England. The next section identifies some areas for consideration to develop ITT programmes so as to challenge the socialisation of trainee physical education teachers and better prepare them to challenge current practice. By doing so we may make physical education relevant to today's young people, whilst working within the constraints of a competency-based model and enabling trainee teachers to meet the specific outcomes to qualify as a teacher.

\section{DEVELOPING KNOWLEDGEABLE TEACHERS OF PHYSICAL EDUCATION ABLE TO MAKE CHANGE}

One area for consideration is changing the focus on ITT programmes from developing knowledge for teaching to developing what Rossi and Cassidy (1999) called 'knowledgeable 
teachers'. Knowledgeable teachers place pupils learning at the heart of their teaching. They are clear about the aims and purposes of physical education and are able to plan their content and teaching approaches to enable them to work towards achieving those aims. They pay as much attention to why they are teaching specific content as to how they are teaching and what teaching approaches they are using. They are able to challenge both their own and others beliefs and practices and the status quo in order to make physical education more relevant to young people. Thus, knowledgeable teachers not only have relevant knowledge and technical expertise for teaching, they are also able to plan what and how they are going to teach so that the curriculum is relevant to the pupil's they are teaching. To achieve this attention needs to be given not only to what knowledge and technical skills trainee teachers need to develop, but also to developing their cognitive capacities to enable them to consider teaching and learning in physical education in a problematic way so that they are able to challenge the content they teach and the teaching approaches they adopt. This also enables them to consider their teaching in any one school more broadly than that specific context.

This requires trainee teachers to be able to reflect and constantly be willing to question teaching approaches; asking questions about how to combine knowledge and delivery methods successfully to transform information into forms that are 'pedagogically powerful', inclusive and inspiring for all pupils (Shulman, 1999). This is further supported through Schon's (1995) view that professional practice should be based on science and not on intuition. This is vital as, in future, teaching and learning will have a complexity that precludes any paint-by-number plan that practitioners can easily stick to (Toole and Seashore Louis, 2002). There is a developing view that the educators of tomorrow in what ever form they take; teachers, coaches, mums, dads, brothers, sisters, volunteers or highly paid professionals will see themselves as 'social pedagogues' (Jones et al 2004), innovators who view their role in the educational relationship differently; challenging their own past in search of a more inclusive, successful and rewarding future.

If reflective skills are to be developed to enable trainee teachers to develop into knowledgeable teachers, not only must they be taught how to reflect, but the right environment must be provided for the skills to be practiced. Further, the methods of assessment must also enable reflection to be rewarded. If priority, and therefore attention, is given on competency-based ITT programmes to trainee teachers providing evidence of 
meeting a number of identified competencies/ standards, then it is that knowledge that is likely to be prioritised and it is unlikely that reflective abilities will be developed.

Consideration therefore also needs to be given to teaching and learning approaches and assessment of both the school- and university-based parts of the programme and to the context in which trainee teachers are located.

Developing reflective practitioners also requires consideration of the content of reflection; of the views of self and others being examined. Reflection needs to focus on more than technical content; more than different views of how to improve the teaching of a particular skill (e.g. different theories of motivation of pupils; effective ways of providing feedback to pupils), which draws on research that takes a technical perspective (e.g. Mosston and Ashworth, 1986; Rink, 1985; Siedentop, 1989, 1991). Rather, reflection must focus on the problematic nature of teaching and learning in physical education (e.g. educational ends and purposes, why the content is as it is and whether this is appropriate, and alternative curriculum models) and therefore draw on research that takes a problematic view of knowledge about teaching (e.g. Kirk, 1986, 1988; Lawson, 1993; Tinning, Kirk and Evans, 1993). Aspects of teaching that cannot be observed and/or which are difficult to measure must therefore be prioritised and must be approached from a problematic perspective. For example, in order to become knowledgeable teachers, Rossi and Cassidy (1999) highlighted that trainee teachers need to develop the ability to reflect on all aspects of physical education so that they can critically evaluate the conventions and routines they have absorbed during their own education and while on school placement as part of their professional preparation to inform their own practice and therefore challenge their own beliefs and values. This may enable them to become NQTs who are better prepared to challenge the status quo. Such an approach gives the greatest likelihood of the strong socialisation, both through own experiences and through the weight of history and tradition of the subject, being challenged. This may require those involved in training teachers to look at teaching and learning more coherently across all aspects of the programme.

According to Mayer (1992) and Sudzina (1997), constructivism is the most frequently used model of learning and teaching in ITT. Knowledge construction involves identifying patterns and regularities and being able to relate ideas to each other in a way that gives meaning to new experience (substantive and syntactic knowledge) (Bruner, 1966). A social constructivist 
approach involves learners in (re)constructing knowledge through a process of interpreting and making sense of new information in terms of their prior knowledge and experience, as a result of interaction among individuals and between one person and their environment (see, for example, Littledyke, 1998; Noel, 2000). It involves participation in a variety of 'hands on' learning experiences which involve interactions with a variety of people, e.g. role play, discussions. These are then examined from the trainee teacher's own as well as others' point of view, and also from theoretical perspectives, explicitly followed up with reflective activity. The insights gained about aspects of teaching and learning are used to inform future practice.

The importance of reflection in the development or construction of knowledge as part of the learning process has been emphasised by many educational theorists. Schon (1983) conceptualised reflection as 'knowledge gained from the practitioner's own experience' through 'reconstructing experience'. To Loughran (1996: 14) reflection is 'the deliberate and purposeful act of thinking which centres on ways of responding to problem situations in teaching and learning'. Although many ITT programmes, including those operating in a competency-based structure, claim to develop reflective practitioners, as indicated above competency-based ITT programmes prioritise the achievement of specific, observable skills through 'concrete, hands on' learning experiences. This suggests that the development of reflective practitioners is given lower priority. Thus, reflection may be 'caught' rather than developed systematically. This may be one reason why Taconis et. al. (2004) questioned whether trainee teachers concentrate too much on being active and seeking concrete experiences and neglect abstract thinking and reflection. Thus, in order to maximise the effectiveness of a constructivist approach consideration needs to be given to whether greater priority should be given to developing skills of reflection.

To engage in reflection trainee teaches must use appropriate cognitive processes and skills. Higher order thinking skills (see, for example, Bloom's taxonomy) enable the examination of the views of others but also, and perhaps more importantly, the examination of (and challenge to) own views and beliefs and values. Some evidence suggests that students enter undergraduate education with a surface approach to learning and that this is maintained throughout their programme (e.g. Entwistle and Tait, 1990; Gow and Kember, 1990; Lawrence et. al., in press; Marton and Saljo, 1997) and into ITT (Marton et. al., 1993; Vermunt, 1996). Learners motivated by the desire to meet minimum requirements with 
minimum effort adopt surface learning approaches. Trainee teachers adopting a surface approach to learning are likely to memorise and reproduce material without analysing or integrating it and to model the teaching approaches of their own teachers and those they observe in schools. Therefore, rather than changing beliefs, prior socialisation is likely to be reinforced. Reflection is likely to be limited to the specific lesson or unit of work and any change is likely to be superficial. Thus, trainee teachers are unlikely to use higher order thinking skills and complex reasoning to challenge a variety of views on the problematic nature of teaching and learning in physical education, which leads to deeper understanding. Without careful planning and structuring of an ITT programme, particularly one based on a competency-based approach, a surface approach to learning is likely to be reinforced.

Thus, consideration needs to be given to whether, and how, trainee teachers can be supported in developing and using deep approaches to learning (see, for example Biggs, 1993, 1999; Entwistle, 1998; Marton and Saljo, 1997; Ramsden, 1992). This will enable them to better understand the material by actively integrating new information with old or with information derived from other sources. This generates higher quality learning outcomes, e.g. the development of analytic skills and improved teaching practice. Trainee teachers adopting a deep approach to learning analyse their own and others teaching approaches and develop their own approaches. Reflection is likely to be deeper, e.g. on the appropriateness of specific content and how it is being taught in relation to the aims and goals of the physical education programme. If a deep approach to learning is to be developed, it needs to be actively promoted (Gordon and Debus, 2002) on ITT programmes. One model that may help is Leach and Moon's (1999) work on pedagogy; teachers, learners, knowledge and learning environment. These can be conceptualised as individual, yet interlinked elements that can be used as a framework for supporting trainee teachers understanding of educational relationships and how knowledge can be translated to support learning; helping trainee teachers to understand the consequences of their pedagogical decisions and choices.

However, it is not enough just to concentrate on the content, teaching and learning and assessment of reflection and the cognitive processes and skills required to reflect. The context in which they are working, and those with whom they are working, must also be considered if trainee teachers are going to be able to develop into reflective practitioners. Thus, consideration needs to be given to the role of school- and university-based staff working on 
ITT programmes, whose role is vital in maximising or hindering the impact of ITT on the trainee teachers ability to reflect. Particular attention should be given to the role of schoolbased mentors as they are particularly influential. School-based mentors and other teachers have power over trainee teachers as they take a large responsibility for their assessment. One outcome of this is that trainee teachers accept the established views of their mentors and copy their mentor, teaching what and how their mentor or other teachers teach (Mawer, 1996). Another likely outcome is that, if there is incongruence between the focus of school- and university-based parts of the programme, trainee teachers are likely to dismiss the universitybased parts of the programme as not relevant to their work in schools. As research (Lortie, 1983) shows, teacher's practice becomes more traditional the longer they are in the profession. It is therefore perhaps worth questioning the potential diet of surface level knowledge received by trainee teachers, reinforced by busy mentors who may not always have the opportunity to reflect critically on their own practice or who do not want to move outside their comfort zone and therefore have great difficulty deconstructing trainees teaching that does not directly resemble their own. Therefore the reactive, intuitive cycle of teacher centred educational practice continues to be reinforced. This further reinforces the opportunities for the overt power dynamic that evidences itself in what is a far from organic mentor-trainee teacher relationship. Thus, the attitudes of all staff, but particularly mentors, and their openness to new practice, are important in either supporting trainee teachers in developing into reflective practitioners or becoming competent technicians.

Thus, one area for development is the role of the mentor and hence the focus of mentor training. Bullock and Wikeley (2004) present a starting point for the mentoring relationship through the 'zone of proximal development', with the mentor viewing themselves as a more capable other, supporting the trainee teacher in the rigorous and complex process of self reflection, thinking about the extent to which their pedagogical choices directly and indirectly support pupil learning and esteem, acknowledging that learning is both active and a social process. In order to achieve this mentor training would need to focus on the mentor adopting the role of significant other who supports the trainee teacher to a position of increased capability in terms of their knowledge, skill and understanding.

Consideration then needs to be given to how mentors can practically support reflection. One area for potential investigation is how mentors and trainee teachers interact within lessons. 
Questions which need to be asked include whether mentors could support a deeper level of reflection on practice through intervention and questioning while the trainee teacher is teaching a lesson (with a pre-agreed arrangement to prevent any unnecessary anxiety on behalf of the trainee teacher). Other questions include whether this strategy would support the trainee teacher in developing an enhanced ability and knowledge of reflection on action; whether it would support trainee teachers formative assessment and planning of subsequent lessons; whether it would further develop trainee teachers ability and awareness of thinking critically about the consequences of their pedagogical choices and how they are received by the learners.

A further consideration is how much trainee teachers are able to develop on a one year ITT programme and therefore what the focus of programmes should be and what the focus of induction and early career development should be. Much research has been conducted on the concerns of trainee physical education teachers (e.g., Behets, 1990; Capel, 1997, 1998a, 1998b; Fuller 1969; Hardy, 1995, 1996; Mawer, 1995; McBride, Boggess and Griffey, 1986). Although the results of some studies (e.g. Boggess, McBride and Griffey, 1985, Fung, 1993, Hardy, 1995, 1997; Meek, 1996; Wendt and Bain, 1989) support a sequential model of development with beginner and pre-service teachers experiencing different concerns, Capel (1997) found that causes and intensity of concern remained the same over the programme of four school experiences on an initial teacher education programme. She suggested that the new environment of each placement results in a refocusing on self concerns rather than sequential development as a teacher. Capel et. al (2006) support this finding for trainee physical education teachers on a PGCE programme. One outcome of this is that it is likely that trainee teachers focus on developing content knowledge and technical expertise to address their immediate concerns and to meet the standards to qualify as a teacher. They therefore may not be able to focus on the learning of individual pupils. This suggests that in ITT the content of reflection may need to be focused on these areas of concern as trainee teachers may not be ready to address teaching and learning in a holistic way, considering their own teaching, content and pupils learning. Thus, when they start their first job, and in the early stages of their career, NQTs need support to continue to develop their teaching; otherwise, they are likely to get better technically, but not to challenge current practice. However, as with trainee teachers, NQTs have no power in the school, therefore it is 
important to ensure that mentors and other teachers have skills and the attitude to encourage reflection.

\section{CONCLUSION}

As currently conceptualised, ITT is a 'low impact' enterprise (Lortie, 1975; Lawson, 1983a). This may be especially true if it focuses on trainee teachers practicing teaching to enable them to acquire a set of pre-defined competencies or skills to meet specified standards. It is argued that if trainee teachers are going to be more than teaching technicians, but are going to be able to develop physical education programmes that are relevant to today's young people, then ITT should focus on more than knowledge for teaching and the technical skills for teaching. ITT, teaching and physical education need to be viewed problematically and critically and focus on developing knowledgeable teachers able to focus on questions of why rather than how. Thus, by placing greater focus in ITT on those aspects of teacher knowledge that are not readily observable and/or that cannot easily be measured, the why as well as the how; on developing cognitive skills, the ability to reflect and challenge own beliefs about the value and purpose of physical education and therefore the content and teaching approaches which are appropriate should empower trainee (and newly qualified) teachers to take a problematic view of teaching and learning in physical education. This enables them to challenge the traditional content and teaching approaches so that physical education becomes more relevant to young people, therefore reduces alienation and encourages participation in physical activity both outside and after leaving school, with its implications for health, including obesity. However, this impact will be lost without school- and university-based staff working with these trainee teachers supporting the development of a problematic view of teaching.

Further, ITT is only a small part of the profession and does not operate in isolation. Trainee teachers work with, and are subject to, pressure of socialisation from all physical educators as well as those outside the profession, including teachers of other subjects, coaches who work in schools as well as those in the community, parents and others including the media. Physical education will not change without a broader challenge to the socialisation of physical education teachers. Thus, consideration also needs to be given to the continuing 
professional development of practicing teachers, as well as to others who work in schools, including coaches.

It seems worth putting effort into both the research agenda and to developing practice on current ITT programmes, to focus on thinking rather than action; on the problematic rather than the technical, on the why rather than how.

\section{REFERENCES}

Alexander, K. and Luckman, J. (2001) Australian teachers' perceptions and uses of the sport education curriculum model, European Physical Education Review, 7 (3), 243-267.

Amade-Escot, C. (2000) The contribution of two research programs on teaching content: 'pedagogical content knowledge' and 'didactics of physical education', Journal of Teaching in Physical Education, 20, 78-101.

Bain, L. (1990) Research in sport pedagogy: past, present and future, in sport and physical activity: moving towards excellence, Proceedings of the AIESEP World Convention, Loughborough University, July.

Behets, D. (1990) Concerns of pre-service physical education teachers, Journal of Teaching in Physical Education, 10, 66-75.

Bennett, N. and Carre, C. (1993) Learning to teach (London, Routledge).

Biggs, J. (1993) From theory to practice: a cognitive systems approach, Higher Education Research and Development, 12 (1), 73-85.

Biggs, J. (1999) Teaching for quality learning at university: what the student does (Buckingham, Open University Press).

Bloom, B.S. (1956) Taxonomy of educational objectives, handbook 1: cognitive domain, (London, Longman).

Boggess, T., McBride, R. and Griffey, D. (1985) The concerns of physical education student teachers: a developmental view, Journal of Teaching in Physical Education, 4, 202-211.

Brown, D. (2005) An economy of gendered practices? Learning to teach physical education from the perspective of Pierre Bordieu's embodied sociology, Sport, Education and Society, 10 (1), 3-23.

Bruner, J. (1966) Towards a theory of instruction (Cambridge, MA, Harvard University Press).

Bullock, K. and Wikeley, F. (2004) Whose learning? The role of the personal tutor (Maidenhead, Open University Press).

Calderhead, J. (1996) Teachers: beliefs and knowledge, in: D.C. Berliner and R.C. Calfree (eds) Handbook of educational psychology (New York, Macmillan), 709-725.

Calderhead, J. and Shorrock, S. B. (1997) Understanding teacher education (London, Falmer Press).

Capel, S. (1997) Reflections on school experiences by PE students learning to teach in secondary school in England and Wales, paper presented at the International Association for Physical Education in Higher Education Conference, Singapore, December.

Capel, S. (1998a) PE students' stages of development as teachers. Part 1: the student's perspective, The British Journal of Physical Education, Autumn, 17-20.

Capel, S. (1998b) PE students' stages of development as teachers. Part 2: the mentor's perspective, The British Journal of Physical Education, Winter, 11-13. 
Capel, S. and Katene, W. (2000) Secondary PGCE PE students' perceptions of their subject knowledge, European Physical Education Review, 6 (1), 46-70.

Capel, S., Hayes, S., Katene, W. and Cook, P. (2006) Secondary student physical education teachers development of knowledge for teaching over the course of a PGCE year, unpublished manuscript.

Carter, K. (1990) Teachers' knowledge and learning to teach, in: W.R. Houston (ed) Handbook of research on teacher education (New York, Macmillan), 291-310.

Cochran-Smith, M. (1991) Learning to teach against the grain, Harvard Educational Review, $61(3), 279-309$.

Cochran-Smith, M. (1995) Color blindness and basket making are not the answers: confronting the dilemmas of race, culture, and language diversity in teacher education, American Educational Research Journal, 32 (3), 465-92.

Cochran-Smith, M. (2001) The outcomes question in teacher education, Teaching and Teacher Education, 17, 527-546.

Corbin, C. (2002) Physical activity for everyone: what every physical educator should know about promoting lifelong physical activity, Journal of Teaching in Physical Education, $21,128-44$.

Curtner-Smith, M.D. (1999) The more things change the more they stay the same: factors influencing teachers' interpretations and delivery of National Curriculum Physical Education, Sport, Education and Society, 4 (1), 75-97.

Department for Education (DfE) (1995) Physical Education in the National Curriculum (London, HMSO).

Department for Education and Employment and Qualifications and Curriculum Authority (DfEE/QCA) (1999) Physical Education: the National Curriculum for England (London, HMSO).

Department for Education and Skills and the Teacher Training Agency (DfES/TTA) (2003) Qualifying to teach: professional standards for qualified teacher status and requirements for initial teacher training (London, TTA).

Department of Education and Science and the Welsh Office (DES/WO) (1992) Physical Education in the National Curriculum (London, HMSO).

Dewar, A. and Lawson, H. (1984) The subjective warrant and recruitment into physical education, Quest, 36, 15-25.

Dodds, P., Placek, J.H., Doolittle, S., Pinkham, K.M., Ratliffe, T.A. and Portman, P.A. (1992) Teacher/coach recruits: background profiles, occupational decision factors, and comparisons with recruits into other physical education occupations, Journal of Teaching in Physical Education, 11, 161-176.

Doolittle, S.A., Dodds, P. and Placek, J.H. (1993) Persistence of beliefs about teaching during formal training of preservice teachers, Journal of Teaching in Physical Education, $12,355-365$.

Edwards, A. and Protheroe, L. (2003) Learning to see in classrooms: what are student teachers learning about teaching and learning while learning to teach in schools? British Educational Research Journal, 29 (2), 227-42.

Elbaz, F. (1983) Teacher thinking: a study of practical knowledge (New York, Nichols Publishing).

Entwistle, N. (1998) Approaches to learning and forms of understanding, in: B. Dart and G. Boulton-Lewis (eds) Teaching and learning in higher education (Camberwell, Vic, ACER), 72-101.

Entwistle, N. and Tait, H. (1990) Approaches to learning, evaluations of teaching, and preferences for contrasting academic environments, Higher Education, 19, 169-94. 
Evans, J. (1992) A short paper about people, power and educational reform. Authority and representation in ethnographic research subjectivity, ideology and educational reform: the case for physical education, in: A. Sparkes (ed) Research in physical education and sport: exploring alternative visions (London, Falmer Press), 231-247.

Evans, J. and Penny, D. (1992) Investigating ERA: qualitative methods and policy oriented research, British Journal of Physical Education Research Supplement, 13, 2-5.

Evans, J. and Williams, T. (1989) Moving up and getting out: the classed and gendered opportunities of physical education teachers, in: T. Templin and P. G. Schempp (eds) Socialization into physical education: learning to teach (Indianapolis, IN, Benchmark Press), 235-251.

Evans, J., Davies, B. and Penney, D. (1995) Pedagogy, identity and difference in physical education, Paper presented at the European Educational Research Association Annual Conference, Bath, September.

Evans, J., Davies, B. and Penney, D. (1996) Teachers, teaching and the social construction of gender relations, Sport, Education and Society, 1, 2, 165-183.

Evans, J., Davies, B., Bass, D. and Penney, D. (1997) Playing for position: education policy, physical education and nationalism in Wales, Journal of Education Policy, 12 (4), 285302.

Fairclough, S. and Stratton, G. (1997) PE curriculum and extra curriculum time in schools in the NW of England, British Journal of Physical Education, 28 (3), 21-24.

Fernandez-Balboa, J.M., Barrett, K., Solomon, M. and Silverman, S. (1996) Perspectives on content knowledge in physical education, Journal of Physical Education, Recreation and Dance, 67, 54-57.

Fletcher, S. (1984) Women first: the female tradition in English physical education 18801980 (London, the Athlone Press).

Flintoff, A. (1993) Gender, physical education and initial teacher education, in: J. Evans (ed) Teachers, teaching and control in physical education (London, Falmer Press), 184-204.

Flintoff, A. and Scraton, S. (2001) Stepping into active leisure? young women's perceptions of active lifestyles and their experiences of school physical education, Sport, Education and Society, 6 (1), 5-21.

Fuller, F.F. (1969) Concerns of teachers: a developmental conceptualisation, American Educational Research Journal, 6 (2), 207-226.

Fung, L. (1993) Concerns among pre- and in-service physical educators, Physical Education Review, 16 (1), 27-30.

Gordon, C. and Debus, R. (2002) Developing deep learning approaches and personal teaching efficacy within a preservice teacher education context, British Journal of Educational Psychology, 72 (4), 483-511.

Gow, L. and Kember, D. (1990) Does higher education promote independent learning? Higher Education, 19 (3), 307-22.

Graber, K. (1995) The influence of teacher education programs on the beliefs of student teachers: general pedagogical knowledge, pedagogical content knowledge and teacher education course work, Journal of Teaching in Physical Education, 14, 157-178.

Green, K. (1998) Philosophies, ideologies and the practice of physical education, Sport, Education and Society, 3, 125-143.

Griffin, L., Dodds, P. and Rovegno, I. (1996) Pedagogical content knowledge for teachers. Integrate everything you know to help students learn, Journal of Physical Education, Recreation and Dance, 67, 58-61.

Grossman, P.L. (1990) The making of a teacher: teacher knowledge and teacher education (New York, Teachers College Press). 
Grossman, P.L., Wilson, S.M. and Shulman, L.E. (1989) Teachers of substance: subject matter knowledge for teaching, in: M.C. Reynolds (ed) Knowledge base for the beginning teacher (New York, Pergamon).

Hardy, C. (1995) Types of teaching problems experienced by pre-service teachers during their predominantly school-based teaching year, British Journal of Physical Education, Winter, 21-24.

Hardy, C. (1996) Trainees' concerns, experiences and needs: implication for mentoring in physical education, in: M. Mawer (ed) Mentoring in physical education: issues and insights (London, Falmer Press), 59-72.

Hardy, C. (1997) Sources of conflict during the school experience of pre-service physical education teachers, European Physical Education Review, 3 (2), 116-128.

Hopkins, D. (2002) A teacher's guide to classroom research, $3^{\text {rd }}$ edn (Maidenhead, Open University Press).

Hoyle, E. and John, P. (1995) Professional knowledge and professional practice (London, Cassell).

Jewett, A.E. (1994) Curriculum theory and research in sport pedagogy, Sport Science Review, 3 (1), 56-72.

Jones, R.L., Armour, K. M. and Potrac, P. (2004) Sports coaching cultures: from practice to theory (London, Routledge).

Kirk, D. (1986) Health related fitness as an innovation in the physical education curriculum, in: J. Evans (ed) Physical education, sport and schooling. Studies in the sociology of physical education (London, Falmer Press).

Kirk, D. (1988) Ideology and the school-centred innovation: A case study and critique, Journal of Curriculum Studies, 20, 449-64.

Kirk, D. (1992) Defining physical education: the social construction of a school subject in postwar Britain (London, Falmer Press).

Kirk, D. and Kinchin, G. (2003) Situated learning as a theoretical framework for sport education, European Physical Education Review, 9 (3), 221-236.

Kirk, D. and Macdonald, D. (1998) Situated learning in physical education, Journal of Teaching in Physical Education, 17, 376-87.

Lawrence, J., Ashford, K. and Dent, P. (in press) Gender differences in coping strategies of undergraduate students and their impact on self-esteem and attainment. Paper to be published in Active Learning in Higher Education.

Laws, C. and Aldridge, M. (1995) Magic moments, myth or millstone - the implementation of national curriculum physical education, British Journal of Teaching Physical Education Research Supplement, 16, 2-12.

Lawson, H. A. (1983a) Toward a model of teacher socialization in physical education: the subjective warrant, recruitment, and teacher education (part 1), Journal of Teaching in Physical Education, 2 (3), 3-16.

Lawson, H. A. (1983b) Toward a model of teacher socialization in physical education: entry into schools, teachers' role orientations, and longevity in teaching (part 2), Journal of Teaching in Physical Education, 3 (1), 3-15.

Lawson, H. A. (1993) Dominant discourses, problem setting, and teacher education pedagogies: a critique, Journal of Teaching in Physical Education, 12 (4), 149-60.

Leach, J. and Moon, B. (eds) (1999) Learners and pedagogy (London, Paul Chapman Publishers).

Leinhardt, G. and Smith, D. (1985) Expertise in mathematics instruction: subject matter knowledge, Journal of Educational Psychology, 77 (3), 241-271.

Lewin, K. (1946) Action research and minority problems, in: G.W. Lewin (ed) Resolving 
social conflicts: selected papers on group dynamics (New York, Harper).

Littledyke, M. (1998) Constructivist ideas about learning, in: M. Littledyke and L. Huxford (eds) Teaching the primary curriculum (London, David Fulton), 1-30.

Locke, F.L. (1992) Changing secondary physical education, Quest, 44, 361-72.

Lortie, D.C. (1975) School teacher: a sociological study (Chicago, Ill, University of Chicago Press).

Loughran, J. (1996) Learning about teaching: a longitudinal study of beginning teachers, Australian Educational Researcher, 23 (2), 55-77.

Marton, F. and Saljo, R. (1997) Approaches to learning, in: F. Marton, D. Hounsell and N. Entwistle (eds) The experience of learning: implications for teaching and studying in higher education, 2nd edn (Edinburgh, Scottish Academic Press), 39-58.

Marton, F., Dall'Alba, G. and Beaty, E. (1993) Conceptions of learning, International Journals of Educational Research, 19 (3), 277-300.

Mawer, M. (1995) Becoming a physical education teacher: pre-service teachers' views and experiences, Bulletin of Physical Education 31 (2), 6-17.

Mawer, M. (1996) Mentoring in physical education: issues and insights (London, Longman).

Mawer, M. (1999) Teaching styles and teaching approaches in physical education: research developments, in: C. Hardy and M. Mawer (eds) Learning and teaching in physical education (London, Falmer Press).

Mayer, R. (1992) Cognition and instruction: their historic meeting within educational psychology, Journal of Educational Psychology, 84 (4), 405-12.

McBride, R.E., Boggess, T.E. and Griffey, D.C. (1986) Concerns of in-service physical education teachers as compared with Fuller's concern model, Journal of Teaching in Physical Education, 5, 149-156.

McDiarmid, G.W. (1990) Challenging prospective teachers' beliefs during an early field experience: a quixotic undertaking? Journal of Teacher Education, 41, 12-20.

McDiarmid, G.W., Ball, D.L. and Anderson, C.W. (1989) Why staying one chapter ahead doesn't really work: subject specific pedagogy, in: M.C. Reynolds (ed) Knowledge base for the beginning teacher (New York, Pergamon).

Meek, G. (1996) The teacher concerns questionnaire with pre-service physical educators in Great Britain: being concerned with concerns, Journal of Teaching in Physical Education, 16, 20-29.

Metzler, M. (ed) (2000) The physical education teacher education assessment project, Journal of Teaching in Physical Education (Special edition), 19 (4).

Mosston, M. and Ashworth, S. (2002) Teaching physical education, 5th edn (San Francisco, Benjamin Cummings).

Munby, H., Russell, T. and Martin, A.K. (2001) Teachers' knowledge and how it develops, in: V. Richardson (ed) Handbook of research on teaching (Washington, American Educational Research Association), 877-904.

Newton, D.P. and Newton, L.P. (2001) Subject content knowledge and teacher talk in the primary science classroom, European Journal of Teacher Education, 24 (3), 369-379.

Noel, K. (2000) Experiencing the theory: constructivism in a pre-service teacher preparation program, Teachers and Teaching: Theory and Practice, 6 (2), 183-96.

O'Bryant, C.P., O'Sullivan, M. and Raudensky, J. (2000) Socialisation of prospective physical education teachers: the story of new blood, Sport, Education and Society, 5, 2, 177-193.

Office for Standards in Education (OfSTED) (1995a) Physical education. a review of inspection findings 1993/94 (London, HMSO).

Office for Standards in Education (OfSTED) (1995b) Physical education and sport in 
schools: a survey of good practice (London, HMSO).

Office for Standards in Education (OfSTED) (1999) Secondary initial teacher training: secondary subject inspections 1996-98 overview report (London, HMSO).

Office for Standards in Education (OfSTED) (2002) Secondary subject reports 2000/01: physical education (London, HMSO).

Office for Standards in Education (OfSTED) (2003) Secondary initial teacher training: secondary physical education subject inspection reports 1999-2003 (London, OFSTED).

Penney, D. (2003) Sport education and situated learning: problematizing the potential, European Physical Education Review, 9 (3), 301-308.

Penney, D. and Chandler, T (2000) Physical education: what future(s)?, Sport, Education and Society, 5 (1), 71-87.

Penney, D. and Evans, J. (1994) It's just not (and not just) Cricket, The British Journal of Physical Education, 25, 9-12.

Penney, D. and Evans, J. (1997) Naming the game: discourse and domination in physical education and sport in England and Wales, European Physical Education Review, 3 (1), 21-32.

Penney, D. and Evans, J. (1999) Politics, policy and practice in physical education (London, FN Spon/Routledge).

Penney, D. and Evans, J. (2005) Policy, power and politics in physical education, in: K. Green and K. Hardman (eds) Physical education essential issues (London, Sage).

Penney, D. and Harris, J. (1998) The national curriculum for physical education: have we got it right? British Journal of Physical Education, 29 (1), 7-10.

Placek, J. (1983) Conceptions of success in teaching: busy, happy and good? in: T. Templin and J. Olsen (eds) Teaching physical education (Champaign, Ill, Human Kinetics), 46-56.

Placek, J.H., Dodds, P., Doolittle, S.A., Portman, P.A., Ratliffe, T.A. and Pinkham, K.M. (1995) Teaching recruits' physical education backgrounds and beliefs about purposes for their subject mater, Journal of Teaching in Physical Education, 14, 246-261.

Ramsden, P. (1992) Learning to teach in higher education (London, Routledge).

Reynolds, M. (1999) Standards and professional practice: the TTA and initial teacher training, British Journal of Educational Studies, 47 (3), 247-60.

Rich, E. (2001) Gender positioning in teacher education in England: new rhetoric, old realities, International Studies in Sociology of Education, 11 (2), 131-55.

Rink, J. (1985) Teaching physical education for learning (St Louis, Times Mirror Mosby).

Rossi, T. and Cassidy, T. (1999) Knowledgeable teachers in physical education: a view of teachers' knowledge, in: C.A. Hardy and M. Mawer (eds) Learning and teaching in physical education (London, Falmer Press).

Rovegno, I. (1992) Learning a new curricular approach: mechanism of knowledge acquisition in preservice teachers, Teaching and Teacher Education, 8, 253-264.

Schempp, P. (1989) Apprenticeship of observation and the development of physical education teachers, in: T.J. Templin and P. Schempp (eds) Socialization into physical education: learning to teach (Indianapolis, IN, Benchmark Press), 13-38.

Schempp, P.G. and Graber, K. (1992) Teacher socialization from a dialectical perspective: pretraining through induction, Journal of Teaching in Physical Education, 11, 329-348.

Schon, D. (1983) The reflective practitioner (London, Ashgate).

Schon, D.A. (1995) The new scholarship requires a new epistemology, Change, 27-34.

Schwab, J.J. (1964) The structure of the disciplines: meanings and significance, in: Ford, G. and Purgo, L. (eds) The structure of knowledge and the curriculum (Chicago, Rand McNally).

Segall, A. (2004) Revisiting pedagogical content knowledge; the pedagogy of content / the 
content of pedagogy, Teaching and Teacher Education, 20, 489-504.

Shulman, L.S. (1986) Those who understand: knowledge growth in teaching, Educational Researcher, 57, 4-14.

Shulman, L.S. (1987) Knowledge and teaching: foundations of a new reform, Harvard Educational Review, 57, 1-22.

Shulman, L.S. (1999) Knowledge and teaching: foundations of the new reform, in: J. Leach and B. Moon (eds) Learners and pedagogy (London, Paul Chapman Publishers), 61-77.

Siedentop, D. (1989) Content knowledge for physical education. Address to the C and I Academy Conference on the Implications of the Knowledge for Teaching for Teacher Education, Boston, AAHPERD.

Siedentop, D. (1991) Developing teaching skills in physical education (Mayfield, CA, Mountain View Press).

Solmon, M.A. and Ashy, M.H. (1995) Value orientations of preservice teachers, Research Quarterly for Exercise and Sport, 66, 219-30.

Sparkes, A.C. (1987) 'Strategic rhetoric': a constraint in changing the practice of teachers, British Journal of Sociology of Education, 8 (1), 37-54.

Sparkes, A.C. (1991a) Curriculum change: on gaining a sense of perspective, in: N. Armstrong and A. Sparkes (eds) Issues in physical education (London, Cassell), 1-19.

Sparkes, A.C. (1991b) Exploring the subjective dimension of curriculum change., in: N. Armstrong and A. Sparkes (eds) Issues in physical education (London, Cassell), 20-35.

Sparkes, A.C. (1992) The changing nature of teacher's work: school governors and curriculum control of physical education, in: N. Armstrong (ed) New directions in physical education, volume 2: towards a national curriculum (Champaign, Ill., Human Kinetics), 1-31.

Stenhouse, L. (1975) An introduction to curriculum research and development (London, Heinemann).

Stidder, G. and Hayes, S. (2006) A longitudinal study of physical education trainee teachers' experiences on school placements in the south-east of England (1994-2004), European Physical Education Review, 12, 317-38.

Sudzina, M.R. (1997) Case study as a constructivist pedagogy for teaching educational psychology, Educational Psychology Review, 9 (2), 199-218.

Taconis, R., van der Plas, P. and van der Sanden, J. (2004) The development of professional competencies by educational assistants in school-based teacher education, European Journal of Teacher Education, 27 (2), 215-40.

Templin, T.J. (1979) Occupational socialisation and the physical education student teacher, Research Quarterly for Exercise and Sport, 50, 482-93.

Thomson, P. (1999) How doing justice got boxed in: a cautionary curriculum tale for policy analysts, in: B. Johnson and A. Reid (eds) Contesting the curriculum (Katoomba, NSW, Social Sciences Press), 24-42.

Tinning, R., Kirk, D. and Evans, J. (1993) Learning to teach physical education (Sydney, Prentice Hall).

Toole, J.C. and Seashore Louis, K. (2002) The role of professional learning communities in international education, in: K Leithwood and P. Hallinger (eds) Second international handbook of educational leadership and administration (London, Kluwer Publishers).

Twiselton, S. (2000) Seeing the wood for the trees: the national literacy strategy and initial teacher education; pedagogical content knowledge and the structure of subjects, Cambridge Journal of Education, 30 (3), 391-403.

Vermunt, J. (1996) Metacognitive, cognitive, and affective aspects of learning styles and strategies: A phenomenonographic analysis, Higher Education, 31, 25-50. 
Wendt, J. and Bain, L. (1989) Concerns of pre-service and in-service physical educators, Journal of Teaching in Physical Education, 8, 177-180.

Williams, A. and Bedward, J. (2001) Gender, culture and the generation gap: student and teacher perceptions of aspects of the National Curriculum Physical Education, Sport, Education and Society, 6 (1), 53-66.

Wright, N. and Buttery, M. (1997) Perceptions of professionalism by the mentors of student teachers, Journal of Education for Teaching, 23 (3), 235-52. 